\title{
Brazilian gutta-percha points. Part II: thermal properties
}

\author{
Cones nacionais de guta-percha. Parte II: \\ propriedades térmicas
}

\begin{abstract}
Cláudio Maniglia-Ferreira ${ }^{(a)}$ Eduardo Diogo Gurgel-Filho(a) João Batista Araújo Silva Jr(b) Regina Célia Monteiro de Paula(c) Judith Pessoa Andrade Feitosa ${ }^{(c)}$ Brenda Paula Figueiredo de Almeida Gomes (d) Francisco José de Souza-Filho(d)
\end{abstract}

(a) PhDs, Department of Endodontics, University of Fortaleza.

(b) PhD Student; (c) Adjunct Professors Department of Organic and Inorganic Chemistry, Federal University of Ceará.

(d) Adjunct Professors, Department of Endodontics, School of Dentistry of Piracicaba, State University of Campinas.

\section{Corresponding author:}

Cláudio Maniglia-Ferreira

R. Bento Albuquerque, 685 - Apto. 1102

Papicu - Fortaleza - CE - Brazil

CEP: 60190-080

E-mail:manigliaf@secrel.com.br

\begin{abstract}
This study was undertaken to explore the effect of heating on gutta-percha, analyzing the occurrence of endothermic peaks corresponding to the transformation that occurs in the crystalline structure of the polymer during thermal manipulation. This study also seeked to determine the temperature at which these peaks occur, causing a transformation from the $\beta$ - to the $\alpha$-form, and from the $\alpha$ - to the amorphous phase. Eight nonstandardized gutta-percha points commercially available in Brazil (Konne, Tanari, Endopoint, Odous, Dentsply 0.04, Dentsply 0.06, Dentsply TP, Dentsply FM) and pure gutta-percha (control) were analysed using differential scanning calorimetry (DSC) and thermogravimetry analysis (TGA). The transition temperatures were determined and analysed. With the exception of Dentsply 0.04 and Dentsply 0.06 , the majority of the products showed thermal behaviour typical of $\beta$-gutta-percha, with two endothermic peaks, exhibiting two crystalline transformations upon heating from ambient temperature to $130^{\circ}$. Upon cooling and reheating, few samples presented two endothermic peaks. It was concluded that heating dental gutta-percha to $130^{\circ} \mathrm{C}$ causes changes to its chemical structure which permanently alter its physical properties.
\end{abstract}

Descriptors: Endodontics; Gutta-percha.

Resumo: Este estudo teve como objetivo analisar, através da Calorimetria Diferencial de Varredura (DSC) e Análise Termogravimétrica (TGA), os efeitos do aquecimento sobre o polímero guta-percha, bem como explorar a ocorrência de picos endotérmicos, os quais correspondem às transformações cristalinas do polímero guta-percha, o que é traduzido em transições de fases (fase $\beta$ para $\alpha$ e fase $\alpha$ para amorfa). Foram utilizadas 8 marcas comerciais de cones de guta-percha não-estandardizados disponíveis no mercado brasileiro (Konne, Tanari, Endopoint, Odous, Dentsply 0.04, Dentsply 0.06, Dentsply TP, Dentsply FM), além da guta-percha pura (controle). As temperaturas de transição foram determinadas e analisadas. Com exceção das amostras Dentsply 0.04 e Dentsply 0.06, todas as demais apresentaram duas transformações cristalinas de fase quando submetidas ao aquecimento da temperatura ambiente até $130^{\circ} \mathrm{C}$, comportamento típico de guta-percha em fase $\beta$. Ao serem resfriadas e reaquecidas, poucas amostras apresentaram dois picos endotérmicos. É possível concluir que o aquecimento a $130^{\circ} \mathrm{C}$ causa danos na estrutura química do polímero guta-percha, o qual altera de forma definitiva suas propriedades físicas. Descritores: Endodontia; Guta-percha. 


\section{Introduction}

According to Gutmann, Witherspoon ${ }^{8}$ (2002), one of the most important criteria for success in endodontics is the tridimensional stability of the root canal filling material. Since Schilder ${ }^{15}$ (1967) introduced the warm vertical condensation technique, a number of clinical placement techniques involving warm gutta-percha have been developed.

The gutta-percha polymer is a trans-1,4-polyisoprene, obtained from the coagulation of latex produced by trees of the Sapotaceae family and mainly derived from Palaquium gutta bail. ${ }^{8,11}$ The crystalline phase appears in two forms: 1) the alpha phase and 2) the beta phase. Transformation occurs in the crystalline structure of the polymer during thermal manipulation which takes place going from the $\beta$ to the $\alpha$-form, and from the $\alpha$ - to the amorphous phase. ${ }^{6}$ The forms differ only in their molecular repeat distance and in their single-bond form. ${ }^{16,17}$

Some studies have related the thermal properties of dental gutta-percha, ${ }^{10,16,20}$ and shown that changes in its crystallographic form may lead to irreversible volumetric changes. ${ }^{3}$

In general, the composition of dental gutta-percha has been shown to be approximately 18 to $22 \%$ gutta-percha polymer and 37 to $75 \%$ zinc oxide. ${ }^{9}$ The particular component percentages vary according to the manufacturer. ${ }^{8,9,18}$ It is evident that since the cones differ in their composition, they may differ in their physical properties, thermal behaviour, ${ }^{16}$ and even in regard to their biological effect. ${ }^{19}$

The purpose of this study was to test, using differential scanning calorimetry (DSC) and thermo- gravimetry analysis (TGA), pure gutta-percha and eight commercially available nonstandardized gutta-percha cones (Konne, Tanari, Endopoint, Odous, Dentsply 0.04, Dentsply 0.06, Dentsply TP and Dentsply FM), and to determine whether there are significant differences in their thermal behaviours.

\section{Material and Methods}

Analysis was performed on the gutta-percha of eight different dental gutta-percha cones commercially available as listed in Table 1. All samples were analysed before their expiry date. All the analyses undertaken were repeated twice for all materials.

The measurements were carried out using two thermal analyses: TGA - Thermogravimetry Analysis (TGA) (Shimadzu TGA-050, Shimadzu Corporation, Tokyo, Japan), and Differential Scanning Calorimetry (DSC) (Shimadzu DSC-50, Shimadzu Corporation, Tokyo, Japan). The calibration of each measurement technique was checked using a calcium oxalate standard. For each material, duplicate samples with between 40 and $50 \mathrm{mg}$ were analysed using $25 \mathrm{mg}$ of alumina as the reference material. ${ }^{3}$

The principle involved is that when a material is heated and undergoes a physical change from one form into another, such as fusion or transitional crystallization, it absorbs or generates heat. ${ }^{10}$ Differential scanning calorimetry is constructed to measure the enthalpic energy of these transformations. The material is kept steady at the same temperature by cooling or heating it, under computer control. When a physical change occurs in the test material (endothermic or exothermic reaction), the appara-

Table 1 - Nonstandardized dental gutta-percha cones selected for study.

\begin{tabular}{|c|c|c|c|}
\hline Gutta-percha cone & Manufacturer/supplier & Batch number & Expiry date \\
\hline Konne & Konne Ind. e Com. de Mat. Odontol., Belo Horizonte, MG, Brazil & $01-05$ & Jan/2008 \\
\hline Tanari & Tanariman Ind. Ltda., Macapuru, AM, Brazil & $001003 G$ & Oct/2007 \\
\hline Endopoint & Endopoints Indústria e Comércio Ltda., Paraíba do Sul, RJ, Brazil & 005 & Jan/2007 \\
\hline Odous & Odous Industrial e Comercial Ltda., Belo Horizonte, MG, Brazil & 09 & May/2006 \\
\hline Dentsply 0.04 & Dentsply Indústria e Comércio Ltda., Petrópolis, RJ, Brazil & 10701 & Nov/2006 \\
\hline Dentsply 0.06 & Dentsply Indústria e Comércio Ltda., Petrópolis, RJ, Brazil & 11106 & Nov/2006 \\
\hline Dentsply TP & Dentsply Indústria e Comércio Ltda., Petrópolis, RJ, Brazil & 8799 & Nov/2006 \\
\hline Dentsply FM & Dentsply Indústria e Comércio Ltda., Petrópolis, RJ, Brazil & 38679 & Apr/2007 \\
\hline
\end{tabular}


tus equalizes the temperature to that of the control. This three-unit apparatus consists of heating, control, and recording systems. ${ }^{10}$

The samples were heated in the analyser to determine the occurrence of endothermic peaks. The transformation temperatures of dental gutta-percha compounds were determined to be 42 to $49^{\circ} \mathrm{C}$ for the $\beta$ - to the $\alpha$-form, and 53 to $59^{\circ} \mathrm{C}$ for the $\alpha$ - to the amorphous form. ${ }^{16}$

All specimens were heated from room temperature to $70^{\circ}$ at a rate of $1^{\circ} \mathrm{C} / \mathrm{min}$, during which time the endothermic peaks were recorded. This was followed by rapid heating to $130^{\circ} \mathrm{C}$. The specimens were then rapidly cooled to room temperature and heated again to $70^{\circ} \mathrm{C}$ at a rate of $1^{\circ} \mathrm{C} / \mathrm{min}$, during which time the endothermic peaks were recorded once more. Simultaneously, thermogravimetric analysis was carried out to determine the weight loss, if any, during the heat cycles. ${ }^{3}$ This analysis consists in eliminating the organic compounds present in the analysed material, and observing its degradation behaviour toward the heat treatment. ${ }^{17}$

\section{Statistical analysis}

The TGA data collected for each sample were entered into a spreadsheet and analyzed statistically using SPSS for Windows (SPSS Inc., Chicago, Ill, USA). The Kruskal-Wallis test was used to compare the percentage of the remaining weight of inorganic compounds found in each gutta-percha brand after heat cycles (Table 2).
The DSC analyses indicate only the presence and the temperature of endothermic peaks of the guttapercha polymer, which occur between $40^{\circ} \mathrm{C}$ and $60^{\circ} \mathrm{C}$, demonstrating the profile of its thermal behavior and indicating the phase in which the polymer is ( $\alpha, \beta$ or amorphous), therefore making the statistical analysis, in this case, unapplicable.

\section{Results}

The experimental data are presented in Table 2. Good agreement was found for temperature peaks between replicate specimens. Typical differential thermal analysis plots are shown in Graphs 1A and B. Dentsply 0.04 and Dentsply 0.06 presented only one endothermic peak in the first run, showing that these materials are different from the others studied in this work.

TGA (Graph 2) showed that all materials had a significant weight loss under the conditions of these experiments (Table 2).

The statistical analyses of the obtained data from TGA indicated that the Dentsply TP and Dentsply FM brands showed the lowest percentages of inorganic compounds $(\mathrm{p}<0.01)$. The Konne, Endopoint and Dentsply 0.04 brands showed results superior to those of Dentsply FM and Dentsply TP ( $<<0.01$ ), but inferior to the results obtained for the Tanari, Odous and Dentsply 0.06 brands $(\mathrm{p}<0.05)$, whose percentages of inorganic compounds were the highest among all brands.

Table 2 - Temperatures $\left({ }^{\circ} \mathrm{C}\right)$ at which endothermic peaks occurred (DSC analysis - run 1 and run 2) and remaining weight (\%) after heat cycles (inorganic components - TGA analysis).

\begin{tabular}{l|c|c|c|c|c}
\hline \multirow{2}{*}{ Gutta-percha brands } & \multicolumn{2}{|c|}{ DSC run 1 } & \multicolumn{2}{c}{ DSC run 2 } & \multirow{2}{*}{ TGA } \\
\cline { 2 - 5 } & Peak 1 & Peak 2 & 50.9 & 61.1 & - \\
\hline Pure gutta-percha & 51.5 & 62.1 & 51.8 & - & 79.71 \\
\hline Konne & 51.7 & 61.1 & 51.3 & - & 81.52 \\
\hline Tanari & 50.7 & 59.9 & 60.8 & - & 79.82 \\
\hline Endopoint & 51.5 & 60.5 & 51.6 & 60.3 & 81.10 \\
\hline Odous & 51.3 & 60.9 & - & 61.7 & 79.88 \\
\hline Dentsply 0.04 & - & 62.3 & - & - & 81.58 \\
\hline Dentsply 0.06 & - & 61.7 & 50.0 & 60.2 & 69.71 \\
\hline Dentsply TP & 48.6 & 61.0 & 50.0 & 69.69 \\
\hline Dentsply FM & 55.7 & 60.0 & & 6 \\
\hline
\end{tabular}



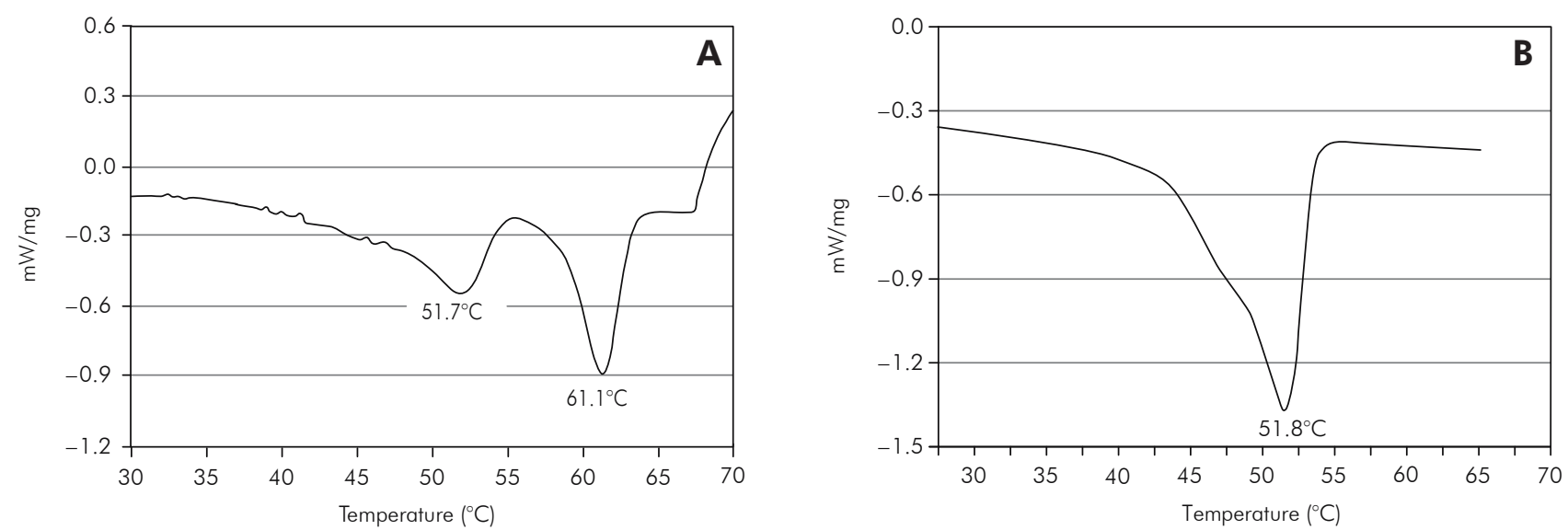

Graphs 1A and B - DSC showing two typical endothermic peaks $\left(51.7^{\circ} \mathrm{C}\right.$ and $\left.61.1^{\circ} \mathrm{C}\right)$, indicating that it was a $\beta$ material (Konne) (A). Only one endothermic peak $\left(51.8^{\circ} \mathrm{C}\right)$ after reheating $(\mathbf{B})$.

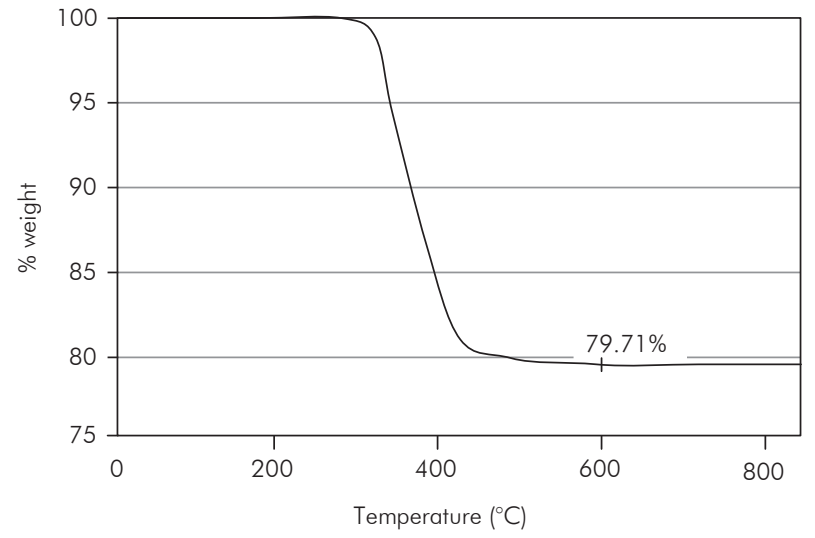

Graph 2 - Thermogravimetric analysis determining the weight loss (organic fraction) during the heat cycle (guttapercha cone Konne).

\section{Discussion}

The objective of root canal filling procedures should be the total three-dimensional filling of the root canal system, a space whose parameters vary infinitely from root to root. ${ }^{15,18}$ Obturation with gutta-percha and sealer during the first appointment, after cleaning and shaping with an anti-septic solution associated to EDTA (to remove the smear layer) ${ }^{4}$ also deprives the remaining microorganisms of their nutrition and leaves them no space to multiply to sufficient numbers to cause or maintain disease. ${ }^{14}$

Chemically pure gutta-percha exists in two distinctly different crystalline forms (alpha and beta) that can be converted from one to the other. The raw materials for the $\alpha$-form are derived directly from the tree. If it is cooled at a rate of more than $0.5^{\circ} \mathrm{C} /$ hour, the $\beta$-form results. ${ }^{5}$ Most commercial guttaperchas, however, are in the $\beta$-crystalline form. There are few physical property differences between the two forms, merely a difference in the crystalline lattice related to the different rates of cooling from the molten form. The $\alpha$ dental form of gutta-percha has a melting point of $64^{\circ} \mathrm{C} . .^{5}$ This form, widely used in making gutta-percha points, is more flexible.

The dental gutta-percha underwent the expected beta to alpha and alpha to amorphous transitions when subjected to thermal testing. ${ }^{16}$

In the present work, except for Dentsply 0.04 and Dentsply 0.06, all the specimens (Table 2) showed two typical endothermic peaks in the first cycle (Graph 1A), indicating that they are composed of $\beta$ form materials. These data agreed with the results obtained by Combe et al. ${ }^{3}$ (2001). For these products, in the second run, only Odous and Dentsply FM presented two peaks. For some specimens, the first peaks occurred at a temperature higher than $53.1^{\circ} \mathrm{C}$, agreeing with the results found by Combe et al. ${ }^{3}$ (2001). Correlations between composition (percentage of gutta-percha - TGA) and thermal behaviour were not found, agreeing with the results found by Marciano, Michailesco ${ }^{10}$ (1989).

The behaviours of Dentsply 0.04 and Dentsply 0.06 were different, consistent with that of a cis polymer, showing that these specimens had either been manufactured using synthetic gutta-percha, or, at the moment of the manufacturing, the tempera- 
ture used to make the cones was so high that the gutta-percha was transformed into its amorphous phase or $c i s-1,4$ polyisoprene. ${ }^{7}$

Differential scanning calorimetry allowed estimates of the thermal range for plasticizing gutta-percha cones, which was determined to be approximately between $40^{\circ} \mathrm{C}$ and $60^{\circ} \mathrm{C} .{ }^{10}$ In endodontic therapy, dental gutta-percha is plasticized by a heat carrier or by thermomechanical compaction, which if used improperly may cause partial decomposition if the heat generated exceeds $100^{\circ} \mathrm{C}$, according to the Merck index. ${ }^{1}$ Root canal filling techniques must use temperature control (between $53^{\circ} \mathrm{C}$ and $59^{\circ} \mathrm{C}$ ) permitting the $\beta$-phase gutta-percha to change into the $\alpha$-phase, avoiding the gutta-percha amorphous phase.

In contrast with the findings of Schilder et al. ${ }^{16}$ (1974), our differential scanning calorimetry results indicated that gutta-percha in the $\beta$-phase begins the $\alpha$-phase change when heat reaches the temperature range of $48.6^{\circ} \mathrm{C}$ to $55.7^{\circ} \mathrm{C}$, and that the $\alpha$-phase material changes to the amorphous phase when heated between $60^{\circ} \mathrm{C}$ and $62^{\circ} \mathrm{C}$. Nevertheless, although the transition temperatures were different, the thermal behaviour of the materials was similar. A new heating cycle after cooling for Konne, Tanari, Endopoint and Dentsply TP showed results that could indicate that either amorphous gutta-percha gets crystallized into $\alpha$-phase and does not return to $\beta$-phase, or the guttapercha polymer has its chemical structure changed in such a way that it becomes cis-1,4 polyisoprene, ${ }^{7}$ which is characterized by one endothermic peak when submitted to any thermal cycling, like Dentsply 0.04 and Dentsply 0.06. Only Odous and Dentsply FM demonstrated two endothermic peaks in a second heating cycle, indicating that the amorphous-phase crystallizes into $\alpha$-phase then crystallizes to $\beta$-phase. On the other hand, a typical cycle up to $130^{\circ} \mathrm{C}$ caused changes in the behaviour of the material.

Reheating produced fewer endothermic peaks, in accordance with Combe et al. ${ }^{3}$ (2001). This cycle could break the chain of covalently bonded atoms, ${ }^{5}$ changing the molecular structure of the gutta-percha polymer and its characteristics when submitted to a heating cycle. $^{2}$ This bonding, along with the natural physical entanglement of the long chains, produces unique and interesting properties in the bulk specimen. . $^{3,5,20}$
The nature and amount of inorganic components in endodontic gutta-percha strongly influence its thermal behaviour. These components do not, however, allow a good control of its mechanical properties. According to Marciano et al. ${ }^{12}$ (1992), the existence of discrepancies between the thermomechanical behaviours of fresh and thermally treated samples demonstrates the importance of the thermodynamic properties of dental gutta-percha. As a consequence, the thermal history of these points is important to their clinical properties. The results of this study show that this parameter is important in clinical applications, during the root canal system filling steps, when choosing the ideal temperature to make the guttapercha cone flow. During clinical treatment, guttapercha should be plasticized under adequate and controlled conditions so as not to be permanently altered and/or lose its chemical characteristics. The use of an uncontrolled heat source can overheat gutta-percha up to close to $300^{\circ} \mathrm{C}$, causing its degradation..$^{16}$ The heat source must be carefully used and the condenser should be heated only for a few seconds before condensing and cutting the obturation material; if overheated, periodontal damages might occur. ${ }^{13}$

Other studies have been undertaken, seeking to correlate physical properties, chemical composition and clinical behaviour to the different root canal materials readily available to the clinician.

\section{Conclusions}

The results of this study indicated that:

- the majority of the products showed a thermal behaviour typical of $\beta$-gutta-percha, with two endothermic peaks;

- Dentsply 0.04 and Dentsply 0.06 showed a behaviour consistent with that of cis- 1,4 polyisoprene; a typical heating cycle up to $130^{\circ} \mathrm{C}$ caused changes in the materials' behaviour (fewer endothermic peaks after reheating);

- the transformation temperatures of dental guttapercha are $48.6^{\circ} \mathrm{C}$ to $55.7^{\circ} \mathrm{C}$ for the $\beta$ - to the $\alpha$ phase transition, and $59.9^{\circ} \mathrm{C}$ to $62.3^{\circ} \mathrm{C}$ for the $\alpha$ - to the amorphous phase transition, depending on the specific compound;

- heating dental gutta-percha to $130^{\circ} \mathrm{C}$ causes physical changes or degradation. 


\section{References}

1. Budavari S, ed. The Merck index: an encyclopedia of chemicals, drugs, and biologicals. $12^{\text {th }}$ ed. Whitehouse Station: Merck; 1996.

2. Cohen BD, Combe EC, Lilley JD. Effect of thermal placement techniques on some physical properties of dental gutta-percha. Int Endod J. 1992;25(6):292-6.

3. Combe EC, Cohen BD, Cummings K. Alpha- and beta-forms of gutta-percha in products for root canal filling. Int Endod J. 2001;34(6):447-51.

4. De Deus GA, Gurgel-Filho ED, Maniglia-Ferreira C, CoutinhoFilho T. Penetração intratubular de cimentos endodônticos. Pesqui Odontol Bras. 2002;16(4):332-6.

5. Friedman CE, Sandrik JL, Heuer MA, Rapp GW. Composition and physical properties of gutta-percha endodontic filling materials. J Endod. 1977;3(8):304-8.

6. Goodman A, Schilder H, Aldrich W. The thermomechanical properties of gutta-percha. II. The history and molecular chemistry of gutta-percha. Oral Surg Oral Med Oral Pathol. 1974;37(6):954-61.

7. Gurgel-Filho ED, Andrade Feitosa JPA, Teixeira FB, Monteiro de Paula RC, Araújo Silva JB, Souza-Filho FJ. Chemical and $\mathrm{X}$-ray analyses of five brands of dental gutta-percha cone. Int Endod J. 2003;36(4):302-7.

8. Gutmann JL, Witherspoon DE. Obturation of the cleaned and shaped root canal system. In: Cohen S, Burns RC, ed. Pathways of the pulp. $8^{\text {th }}$ ed. St. Louis: Mosby; 2002. p. 293-364.

9. Maniglia-Ferreira C, Silva Jr JBA, Paula RCM, Feitosa JPA, Cortez DGN, Zaia AA et al. Brazilian gutta-percha points. Part I: chemical composition and X-ray diffraction analysis. Braz Oral Res. 2005;19(3):193-7.

10. Marciano J, Michailesco PM. Dental gutta-percha: chemical composition, X-ray identification, enthalpic studies, and clinical implications. J Endod. 1989;15(4):149-53.
11. Marciano J, Michailesco PM, Abadie JM. Stereochemical structure characterization of dental gutta-percha. J Endod. 1993;19(1):31-4.

12. Marciano J, Michailesco PM, Charpentier E, Carrera L, Abadie JM. Thermomechanical analysis of dental gutta-percha. J Endod. 1992;18(6):263-70.

13. Mc Cullagh JJ, Setchell DJ, Gulabivala K, Hussey DL, Biagioni $\mathrm{P}$, Lamey PJ et al. A comparison of thermocouple and infrared thermographic analysis of temperature rise on the root surface during the continuous wave of condensation technique. Int Endod J. 2000;33(4):326-32.

14. Peters LB, Wesselink PR, Moorer WR. The fate and role of bacteria left in root dentinal tubules. Int Endod J. 1995;28(2):959.

15. Schilder H. Filling root canals in three dimensions. Dent Clin North Am. 1967;11:723-44.

16. Schilder H, Goodman A, Aldrich W. The thermomechanical properties of gutta-percha. III. Determination of phase transition temperatures for gutta-percha. Oral Surg Oral Med Oral Pathol. 1974;38(1):109-14.

17. Silva Jr JBA, Paula RCM, Feitosa JPA, Gurgel-Filho ED, Maniglia-Ferreira C, Souza-Filho FJ. In vivo aging of gutta-percha dental cone. J Appl Polym Sci. 2006;100(5):4082-8.

18. Spångberg LSW. Instruments, materials, and devices. In: Cohen S, Burns RC, ed. Pathways of the pulp. $8^{\text {th }}$ ed. St. Louis: Mosby; 2002. p. 521-72.

19. Tagger M, Gold A. Flow of various brands of gutta-percha cones under in vitro thermomechanical compaction. J Endod. 1988;14(3):115-20.

20. Tay FR, Pashley DH, Williams MC, Raina R, Loushine RJ, Weller RN et al. Susceptibility of a polycaprolactone-based root canal filling material to degradation. I. Alkaline hydrolysis. J Endod. 2005;31(8):593-8. 